\title{
Students` Responses in Enhancing New Vocabulary Through Subtitled English Movies
}

\author{
Caroline V. Katemba \& Wei Ning \\ Correspondence author Caroline (linakatemba@gmail.com) \\ School of Education, Universitas Advent Indonesia \\ DOI: https://doi.org/10.35974/acuity.v3i1.623
}

\begin{abstract}
Name of Journal
ACUITY: JOURNAL OF ENGLISH LANGUAGE PEDAGOGY, LITERATURE, AND

CULTURE, VOL 3 NO 1 Published 2018-02-01

URL: https://jurnal.unai.edu/index.php/acuity/article/view/623
\end{abstract}

\begin{abstract}
This study aims to find out the student responses in enhancing new vocabulary through subtitled English Movies. And the research question is what are students 'responses in enhancing new vocabulary through subtitled English movies? to achieve this objective, the study employed a quantitative method. The data were obtained from the questionnaire. The questionnaire was distributed to the Universitas Advent Indonesia. The data were then descriptively analyzed. The result of this study indicated that most of the students responded positively through subtitled English movies in enhancing new vocabulary. These research findings are expected to contribute to the efforts in the teaching and learning area, particularly in increasing students' vocabulary.
\end{abstract}

Keywords: Subtitled English Movies, Student`Responses, Vocabulary

\section{Introduction}

One of the requirements of having the ability to communicate in English is by having adequate vocabulary. Knowing vocabulary will help students speak, write, read and listen to the language. In teaching English vocabulary as an element of language is considered a very important factor in increasing the English language if the students are still lacking of vocabulary.

Lein (2006) stated that "as a matter of fact, English is a foreign language for Indonesian students and they have learned it from kindergarten until university 
level. English language is still considered a difficult subject for Indonesian students because English language model is different from Indonesia" (p.23).

Knowing the importance of the vocabulary, many strategies have been applied in enhancing vocabulary, and researchers have found a way in enhancing new vocabulary from other research that by watching English movies can improve new English vocabulary. According to Putra (2014) movies or media can be an effective tool for learning new vocabulary "there is no doubt that video technology especially subtitled movies can be a powerful teaching tool to help students learn and acquire new vocabulary" (p.7).

In foreign language teaching-learning process, vocabulary plays an important role. It is one element that links the four skills of speaking, reading, listening and writing altogether. (Nguyen \& Khuat, 2003). According to Schmitt. (2000, p.149) "Teaching vocabulary is such an important task in teaching English because vocabulary achievement relates to all language learning and it is of concern to all four language skills"

Shoebottom (2010) mentioned that vocabulary mastering is more important than grammar. It is the key for students to understand what they hear, read and write in learning English and how to communicate with other people. For this reason, it is very important if students can quickly build up a language store of words. Wilkins (1972) wrote that "while without grammar very little can be conveyed, without vocabulary nothing can be conveyed" (Pp 111-112) This point reflects that even without grammar, but with some useful words it can help people especially English students to acquire more productive vocabulary knowledge and to develop their vocabulary.

According to Sukrina, (2010) vocabulary is very essential to comprehend the language well to be able to speak comprehend the language well, speak better, or compose a good writing. It is expected that the students have to increase their vocabulary of about 100 words a year. Similarly, on the Competence-Based Curriculum, the students are required to increase their vocabulary 1000-1500 words every year so that in three years students have increased their vocabulary around 4000 words. Bayrne (1983) pointed out a fact of unsuccessful achievement of learning English; one of them is a vocabulary mastery.

From the researcher's experience as an English Major who studies at UNAI, in the process of studying English, the researcher had many problems in mastering English words and difficulties to express ideas or feelings especially because the researcher lacked new vocabulary. It means that the English words in the researcher's mind are limited so it is hard to understand the speaker. Therefore 
without having good vocabulary, there will be a breakdown in communication. Students should know that vocabulary is vital for them (Ghozali 2005).

In addition to Sukrina (2010) In fact, most of the students had many problems in vocabulary mastery. In the process of learning English, the students are weak in using the vocabulary. They had limited vocabulary to comprehend the meaning of a text; they could not recognize the meaning of each word, and they get difficulties to state some sentences in English. Those problems cause them to have difficult communication in English.

Edge (1993, p.27) points out: "Knowing a lot of words in a foreign language is very important. The more vocabulary the students know, the easier the students can understand the foreign language."

In Indonesia, there has been a study on "enhancing vocabulary using English movie with subtitled by Weyers. (1999). This study explained there is no doubt that video technology especially subtitled movies can be a powerful teaching tool to help students learn and acquire new vocabulary. Watching subtitled movie more than once might develop other skills of the students, such as reading or listening comprehension, and even pronunciation. Watching English movies with subtitled is actually can be an effective method to improve the English vocabulary.

In China, According to Wang and Zhang (2012), nowadays, most of the college students in China have the experience of watching an English movie in class. Some students like the strategy to learn English through movies because they can learn a lot from the characters' personality, their attitudes towards life, and cultural background in different countries besides language.

Sukrina (2013) stated that students learn vocabulary quickly by using media such as wall charts, real objects, videos, movies, internet, etc; because media can give context to them. Moreover creating activities using media can keep the meaning of the words in their mind and can stand longer.

As King (2002) stated movies provide more pedagogical options and are a rich resource of intrinsically motivating materials for students. When students are exposed to movies, they can learn some words and phrases used in the movies and by using subtitled movies, students can learn how to pronounce many words, and also help them to acquire new vocabulary and idioms. The use of subtitled movies may be effective to improve the reading and listening comprehension, word recognition and vocabulary acquisition of students (Putra, 2014). 
Form the information above, the researcher is interested to study on the "students' responses in enhancing new vocabulary through watching subtitled movies."

Based on the background above, this study is conducted to answer the following research question:

\section{"What are students' responses in enhancing new vocabulary through subtitled English movies?"}

Through this study, the researcher expects the result will be able to support and provide the benefit for students, English major students, English teachers, the university and the researcher for the future.

To give insights for the future researchers to venture into a similar study that will use a different population.

The result of this study is expected to help teachers see another way of teaching new vocabulary through subtitled English movies.

In this study, the researcher took the data from the students of Universitas Advent Indonesia (UNAI) Bandung West Java as a place to be observed. As the researcher is also a student in UNAI, the researcher observed that most of the students have a problem in learning new vocabulary, not only in general classes also in English major classes. Based on the fact above, the researcher focused on the research entitled students' responses in enhancing new vocabulary through watching subtitled English movies. The researcher used random sampling to choose 100 students in this university and distribute the survey. Those students were questioned about their enhancing new vocabulary through watching subtitled English movies

The purpose of this study is to know whether through subtitled English movies will enhance new vocabulary.

\section{Research Methodology}

This study is a surveying research design. According to Mcchester and Ihedigbo (2014), surveying research design represents one of the most common types of quantitative social science research. In survey research, researchers select a sample of respondents from the population and administers a standardized questionnaires to them. The researcher used this method to find out the students' 
responses in using subtitled English movies in enhancing vocabulary. This research is quantitative.

The population of this study was the Universitas Advent Indonesia's students in Bandung, West Java. The total number of the students was 100 students from Education, Nursing and Business students at Universitas Advent Indonesia in Bandung, West Java.

The use of questionnaires as the instrument in this study was the students' responses to the use of English movies with subtitles in enhancing vocabulary.

In the questionnaire, the main instrument that was used for this study was a self-designed survey. In this study, the respondents read the questions, interpreted what is expected and then write down the answers. The Form of this study consisted of fifteen questions with five answers: Strongly Agree (SA), Agree (A), Uncertain (UC), Disagree (DA), and Strongly Disagree (SDA). Based on the Likert scales, each statement in the questionnaire consisted of a value from 1-5 which 5 is the most positive answer (Strongly Agree). In the survey, the researcher used a positive statement. Leung (2001) suggested if possible to avoid negative statements when designing a survey. The scoring system of the questionnaire was classified according to the following Table 1.

Table 1

The Table of Scoring System of the Questionnaire

\begin{tabular}{|l|l|l|l|l|l|}
\hline Statements & Strongly & Agree & Uncertain & Disagree & Strongly \\
(Answers) & Agree & & & & Disagree \\
\hline Value & 5 & 4 & 3 & 2 & 1 \\
\hline
\end{tabular}

\section{Procedure of Data Gathering}

In gathering the data the researcher distributed the questionnaires to the sample. The researcher asked the students to be honest to answer the questionnaire. Before they answer the questionnaire, the researcher gave a detailed explanation to 
them about how to complete the questionnaire. The researcher distributed the questionnaires to the students at Universitas Advent Indonesia Education, Nursing and Business students in Bandung, West Java. The total number of the sample in this research was one hundred. The data was gathered in the month of January and February 2017.

The pilot-test measured the validity and reliability level of the instrument. The valid and reliable items were used as research instrument.

It was administered to a group of students at UNAI.

Validity test intends to figure out if an instrument test is appropriate to be used in the research or not. The following formula measures the validity of the instrument according to Arikunto (2012):

$$
r_{x y}=\frac{n \Sigma X Y-(\Sigma X)(\Sigma Y)}{\sqrt{\left\{n \Sigma X^{2}-(\Sigma X)^{2}\right\}\left\{n \Sigma Y^{2}-(\Sigma Y)^{2}\right\}}}
$$

Where:

$r_{x y}$ : Correlation coefficient

$n$ : Number of subject

$x$ : Item score

$y$ : Total score

The classification of validity is shown in the following table 2 :

Table 2

Classification of Validity Question

\begin{tabular}{|l|l|}
\hline \multicolumn{1}{|c|}{$r_{x y}$} & Interpretation \\
\hline$\leq 0.00$ & Not Valid \\
\hline $0.00-0.20$ & Very Low \\
\hline $0.21-0.40$ & Low \\
\hline $0.41-0.60$ & Moderate \\
\hline
\end{tabular}




\begin{tabular}{|l|l|}
\hline $0.61-0.80$ & High \\
\hline $0.81-1.00$ & Very High \\
\hline
\end{tabular}

Source: Muhammad (2008)

\section{Content Validity Evaluator}

Content validity evaluators were from the English department lecturers. The questionnaire was checked and approved by:

1. Mr. Nelson Balisar Panjaitan, MA

2. Mrs. Debora Chaterin Simanjuntak, MA.ED

3. Mrs. Caroline V Tobing Ph.D

4. Mrs. Anas Barus Situmeang, MPH

5. Mrs. Leong Jin, MA, TESOL

Arikunto (2012) stated that an instrument is reliable if the test has the same result even after being done many times. Thus it is reliable to collect the data required.

The following is the formula which is used to find the reliability of the instrument:

$$
r_{11}=\left(\frac{n}{n-1}\right)\left(\frac{S^{2}-\Sigma p q}{S^{2}}\right)
$$

Where:

$$
\begin{array}{ll}
r_{11} & : \text { Reliability of all test } \\
\mathrm{n} & : \text { total number of question } \\
\mathrm{p} & : \text { subject proportion for the right answer } \\
\mathrm{q} & : \text { subject proportion for the wrong answer }(q=1-p) \\
S^{2} & : \text { Standard deviation of the test } \\
\Sigma p q & : \text { The result of } \mathrm{p} \text { times } \mathrm{q}
\end{array}
$$

Classification of the reliability coefficient is shown in the table below: 
Table 3

Classification of Reliability Test

\begin{tabular}{|l|l|}
\hline Amount of $r_{11}$ & Interpretation \\
\hline$r_{11} \leq 0.20$ & Very Low \\
\hline $0.21 \leq r_{11} \leq 0.40$ & Low \\
\hline $0.41 \leq r_{11} \leq 0.70$ & Moderate \\
\hline $0.71 \leq r_{11} \leq 0.90$ & High \\
\hline $0.91 \leq r_{11} \leq 1.00$ & Very High \\
\hline
\end{tabular}

Source: Muhammad (2008)

In this part, the researcher used Microsoft Excel to count the total score from the survey answered by the respondents. The results showed the total score of each factor and which factor has the highest score that affects students' responses in enhancing new vocabulary.

\section{Result}

To test the validity of the instrument used, in this study, the researcher analyzed the data gathered statistically and then compared the value with the criteria set at table 4.1 to decide the valid statements.

Table 4

Validity Coefficient

\begin{tabular}{|l|l|}
\hline Validity Coefficient Value & Interpretation \\
\hline Above 0.35 & Very beneficial \\
\hline $0,21-0.35$ & Likely to be useful \\
\hline $0.11-0.20$ & Depends on circumstances \\
\hline Bellow 0.11 & Unlikely to be useful \\
\hline
\end{tabular}

Garcia (2011) 
The following is the result of the validity test. There are 45 statements. The following table 4.2 shows the 5 most significant items (Q33, Q38, Q41, Q43, Q45), 2 most insignificant items (Q3, Q28) and 3 most low significant items (Q6, Q36, Q40).

Table 5

Validity Test

\begin{tabular}{|c|c|c|c|}
\hline $\mathrm{NO}$ & Correlation \& Sig & Responses Test & Information \\
\hline \multirow[t]{3}{*}{ Q33 } & Pearson Correlation & .717 & \multirow[t]{3}{*}{ Valid } \\
\hline & Sig. (2-tailed) & .000 & \\
\hline & $\mathrm{N}$ & 30 & \\
\hline \multirow[t]{3}{*}{ Q38 } & Pearson Correlation & .671 & \multirow[t]{3}{*}{ Valid } \\
\hline & Sig. (2-tailed) & .000 & \\
\hline & $\mathrm{N}$ & 30 & \\
\hline \multirow[t]{3}{*}{ Q41 } & Pearson Correlation & .679 & \multirow[t]{3}{*}{ Valid } \\
\hline & Sig. (2-tailed) & .000 & \\
\hline & $\mathrm{N}$ & 30 & \\
\hline \multirow[t]{3}{*}{ Q43 } & Pearson Correlation & .676 & \multirow[t]{3}{*}{ Valid } \\
\hline & Sig. (2-tailed) & .000 & \\
\hline & $\mathrm{N}$ & 30 & \\
\hline \multirow[t]{3}{*}{ Q45 } & Pearson Correlation & .683 & \multirow[t]{3}{*}{ Valid } \\
\hline & Sig. (2-tailed) & .000 & \\
\hline & $\mathrm{N}$ & 30 & \\
\hline \multirow[t]{3}{*}{ Q3 } & Pearson Correlation & -.040 & \multirow[t]{3}{*}{ Not Valid } \\
\hline & Sig. (2-tailed) & .834 & \\
\hline & $\mathrm{N}$ & 30 & \\
\hline \multirow[t]{2}{*}{ Q6 } & Pearson Correlation & .099 & \multirow[t]{2}{*}{ Low valid } \\
\hline & Sig. (2-tailed) & .601 & \\
\hline
\end{tabular}




\begin{tabular}{|l|l|l|l|}
\hline & $\mathrm{N}$ & 30 & \\
\hline \multirow{4}{*}{ Q28 } & Pearson Correlation & -.057 & \multirow{2}{*}{ Not valid } \\
\cline { 2 - 3 } & Sig. (2-tailed) & .766 & \\
\cline { 2 - 3 } & $\mathrm{N}$ & 30 & \multirow{2}{*}{ Low valid } \\
\hline \multirow{2}{*}{ Q36 } & Pearson Correlation & .107 & \\
\cline { 2 - 3 } & Sig. (2-tailed) & .572 & \multirow{2}{*}{ Low valid } \\
\cline { 2 - 3 } & $\mathrm{N}$ & 30 & \\
\hline Q40 & Pearson Correlation & .124 & .513 \\
\cline { 2 - 3 } & Sig. (2-tailed) & 30 & \\
\cline { 2 - 3 } & N & & \\
\hline
\end{tabular}

In the table, the Pearson Correlation is bigger than the coefficient value $0.21-0.35$ (Likely to be useful) and 0.35 (very beneficial), and if the significant level is less than 0.05 , then the statement can be considered statistically significant and valid. 35 statements were used in this study.

This study used the test of reliability to see if the instrument is reliable or not. These reliability result for the pilot test of the instrument was calculated by using SPSS 20, the result of Cronbach's alpha was .900, which was classified into the high category as a result, and it was very reliable to be used as the research instrument. The following table shows the reliability analysis scale.

Table 6

Reliability Statistics

\begin{tabular}{|l|l|}
\hline Cronbach's Alpha & N of Items \\
\hline .916 & 35 \\
\hline
\end{tabular}

From the table 6 above shows that the Cronbach's Alpha value is 0.916 or $91.6 \%$, then it is bigger than 0.50 or $50 \%$. It mean that the list of question are reliable. 
The researcher used Excel for tallying the data to find out the number of students' answers with each statement. The following table is the summary of tallying the Data.

Table 7

The Summary of Tallying the Data.

\begin{tabular}{|c|c|c|}
\hline \multirow{10}{*}{$\begin{array}{l}\text { I. Enhancing new } \\
\text { Vocabulary }\end{array}$} & 1. & $\begin{array}{l}82 \% \text { of the students agreed that they can learn } \\
\text { many new words from watching subtitled } \\
\text { English movies. }\end{array}$ \\
\hline & 2. & $\begin{array}{l}74 \% \text { of the students agreed that they can } \\
\text { understand when they watch subtitled English } \\
\text { movies. }\end{array}$ \\
\hline & 3. & $\begin{array}{l}\text { There were } 28 \% \text { of the students agreed that } \\
\text { they understand all vocabulary in their English } \\
\text { test. }\end{array}$ \\
\hline & 4. & $\begin{array}{l}56 \% \text { of the students agreed that they can tell } \\
\text { slight differences between words, for example, } \\
\text { "big" and "huge". }\end{array}$ \\
\hline & 5. & $\begin{array}{l}86 \% \text { of the students agreed that they want to } \\
\text { know the meaning when they watch English } \\
\text { movie. }\end{array}$ \\
\hline & 6. & $\begin{array}{l}67 \% \text { of the students agreed when the teacher } \\
\text { tells the instructions they understand better. }\end{array}$ \\
\hline & 7. & $\begin{array}{l}67 \% \text { of the students agreed they can usually } \\
\text { have several vivid mental pictures and/or } \\
\text { sounds of situations when they are imagining } \\
\text { themselves using English skillfully in the } \\
\text { future. }\end{array}$ \\
\hline & 8. & $\begin{array}{l}44 \% \text { of the students agreed they understand } \\
\text { every word when their teacher speaks in } \\
\text { English. }\end{array}$ \\
\hline & 9. & $\begin{array}{l}88 \% \text { of the students agreed they like to } \\
\text { enhance new vocabulary. }\end{array}$ \\
\hline & 10. & $\begin{array}{l}67 \% \text { of the students agreed they learn many } \\
\text { vocabulary from the listening material. }\end{array}$ \\
\hline
\end{tabular}




\begin{tabular}{|c|c|c|}
\hline & 11. & $\begin{array}{l}51 \% \text { of the students agreed their teacher helps } \\
\text { them learning new vocabulary every day. }\end{array}$ \\
\hline \multirow[t]{8}{*}{$\begin{array}{l}\text { II. The Knowledge of } \\
\text { learning Background }\end{array}$} & 1. & $\begin{array}{l}72 \% \text { of the students agreed they learn } \\
\text { vocabulary from subtitles when they watch } \\
\text { English movies. }\end{array}$ \\
\hline & 2. & $\begin{array}{l}75 \% \text { of the students agreed they like English } \\
\text { movies. }\end{array}$ \\
\hline & 3. & $\begin{array}{l}64 \% \text { of the students agreed they record } \\
\text { vocabulary from English soundtrack movies in } \\
\text { their notebook. }\end{array}$ \\
\hline & 4. & $\begin{array}{l}58 \% \text { of the students agreed they learned } \\
\text { vocabulary by watching the movies then they } \\
\text { try to remember words and repeatedly. }\end{array}$ \\
\hline & 5. & $\begin{array}{l}34 \% \text { of the students agreed they do not worry } \\
\text { very much about the difficult words found } \\
\text { when reading or listening, they pass them. }\end{array}$ \\
\hline & 6. & $\begin{array}{l}53 \% \text { of the students agreed they use online } \\
\text { exercise to test their vocabulary knowledge. }\end{array}$ \\
\hline & 7. & $\begin{array}{l}57 \% \text { of the students agreed they write a new } \\
\text { word in a sentence so they can remember it. }\end{array}$ \\
\hline & 8. & $\begin{array}{l}58 \% \text { of the students agreed they speak words } \\
\text { out loud when they study. }\end{array}$ \\
\hline \multirow{5}{*}{$\begin{array}{l}\text { III. Students' personal } \\
\text { feeling and attitude } \\
\text { toward the } \\
\text { implementation of } \\
\text { subtitled English } \\
\text { movies }\end{array}$} & 1. & $\begin{array}{l}39 \% \text { of the students agreed they prefer } \\
\text { watching movies with dual subtitles. }\end{array}$ \\
\hline & 2. & $\begin{array}{l}69 \% \text { of the students agreed they prefer } \\
\text { watching movies with subtitled English } \\
\text { movies. }\end{array}$ \\
\hline & 3. & $\begin{array}{l}54 \% \text { of the students agreed they always look } \\
\text { forward to English classes. }\end{array}$ \\
\hline & 4. & $\begin{array}{l}52 \% \text { of the students agreed when they have } \\
\text { free time to relax, they prefer to watch an } \\
\text { English movie. }\end{array}$ \\
\hline & 5. & $\begin{array}{l}67 \% \text { of the students agreed they try having } \\
\text { conversations using the new words with } \\
\text { English speakers e.g. teachers, etc. }\end{array}$ \\
\hline
\end{tabular}




\begin{tabular}{|l|l|l|}
\hline 6. & $\begin{array}{l}45 \% \text { of the students agreed they read the new } \\
\text { words } 2 \text { or } 3 \text { times first, again a few days later, } \\
\text { a week later, a month later. }\end{array}$ \\
\hline 7. & $\begin{array}{l}82 \% \text { of the students agreed that learning } \\
\text { vocabulary from subtitled movies is an } \\
\text { interesting way. }\end{array}$ \\
\hline 8. & $\begin{array}{l}68 \% \text { of the students agreed they prefer to learn } \\
\text { vocabulary from subtitled movies rather than } \\
\text { from books. }\end{array}$ \\
\hline 9. & $\begin{array}{l}74 \% \text { of the students agreed The Subtitled } \\
\text { movie makes vocabulary learning easy. }\end{array}$ \\
\hline 10. & $\begin{array}{l}82 \% \text { of the students agreed English movies } \\
\text { improve their English vocabulary. }\end{array}$ \\
\hline 11. & $\begin{array}{l}59 \% \text { of the students agreed Movies should be } \\
\text { used in the EFL classroom. }\end{array}$ \\
\hline 12. & $\begin{array}{l}76 \% \text { of the students agreed they think movies } \\
\text { are a useful resource for oral English language } \\
\text { teaching. }\end{array}$ \\
\hline 13. & $\begin{array}{l}75 \% \text { of the students agreed the feedback they } \\
\text { received from students when using movies in } \\
\text { teaching has been positive. }\end{array}$ \\
\hline 14. & $\begin{array}{l}76 \% \text { of the students agreed they think movies } \\
\text { are a useful resource for teaching English } \\
\text { vocabulary. }\end{array}$ \\
\hline 15. & $\begin{array}{l}75 \% \text { of the students agreed a movie review is } \\
\text { more motivating for the students than a book } \\
\text { review. } \\
\text { learning English. }\end{array}$ \\
\hline
\end{tabular}

The students' responses in enhancing new vocabulary through subtitled English movies is the affective response. This response deals with students' personal feelings and attitudes toward the implementation of watching subtitled English movies. 
According to the pie chart of figure 1, it was found that $82 \%$ of students agreed and strongly agreed that they can learn many new words from watching subtitled English movies. While there was only $18 \%$ of the students disagreed. This response answered the statement number 2 .

According to the pie chart of figure 2 on the next page, $74 \%$ of students agreed and strongly agreed that they can understand when they watch subtitled English movies. On the other hand, there was $27 \%$ of the students disagreed. This response was from statement number 2 . The pie chart in the next is the result from statement number 1 and 2.

Figure 2
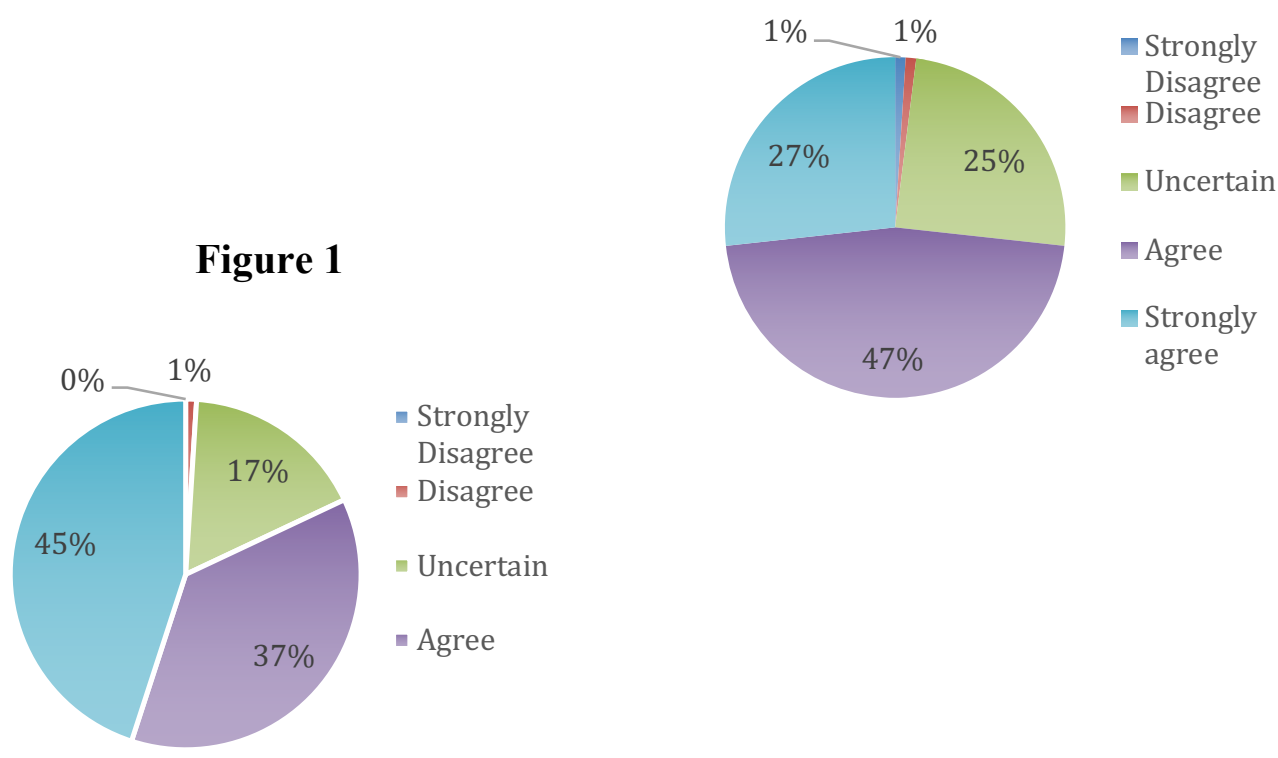

Based on the pie chart of figure 3 on the next page, it was found that $28 \%$ of students agreed and strongly agreed that they understand all vocabulary in their English test. While $72 \%$ of the students disagreed. It means the students are weak in their vocabulary. This response answered the statement number 3.

Based on the pie chart of figure 4 in the next page, $56 \%$ of the students agreed and strongly agreed that they can tell the slight differences between words, for example, "big" and "huge". It meant the students know a similar vocabulary. On 
the other hand, $43 \%$ of the students could not know. This was the students' response from statement number 4 . The pie chart in the next is the result from statement number 3 and 4.

Figure 3

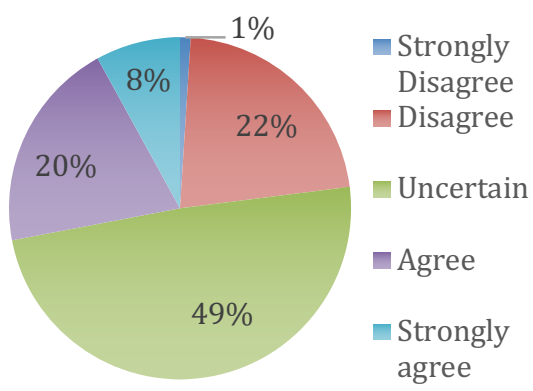

\section{Figure 4}

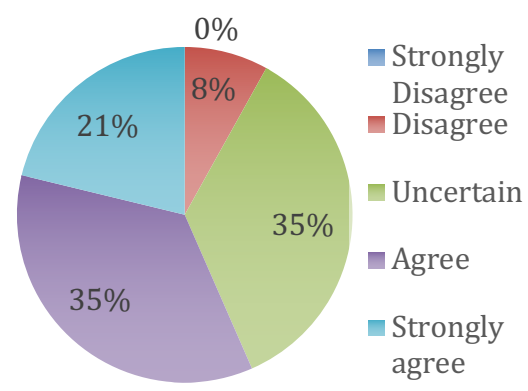

In the pie chart of figure 5 , it was found that $86 \%$ of the students agreed and strongly agreed that they want to know the meaning when they watch English movie. Only $14 \%$ of the students disagreed. This response answered the statement number 5.

In the pie chart of figure $6,67 \%$ of the students agreed and strongly agreed when the teacher tells them the instructions they understand better. While $33 \%$ of the students disagreed. This was the students' response with the statement number 6 . The pie chart below is the result from statement number 5 and 6 .

Figure 5

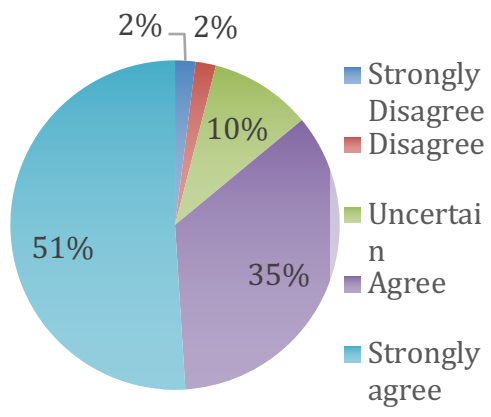

Figure 6

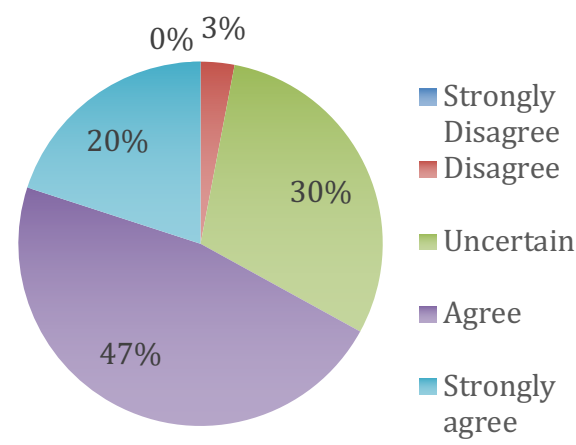

According to the pie chart of figure 7 , it was found that $67 \%$ of the students agreed and strongly agreed that they can usually have several vivid mental pictures 
and/or sounds of situations when they are imagining myself using English skillfully in the future. In the other hand, 33\% of the students disagreed. This response was statement number 7 .

Figure. 8 showed that $44 \%$ of the students agreed and strongly agreed they understand every word when their teacher speaks in English. 15\% of the students could not understand every word when their teacher speaks in English. This response was a statement with the number 8 . The pie chart below is the result of statement number 7 and 8 .

\section{Figure 7}

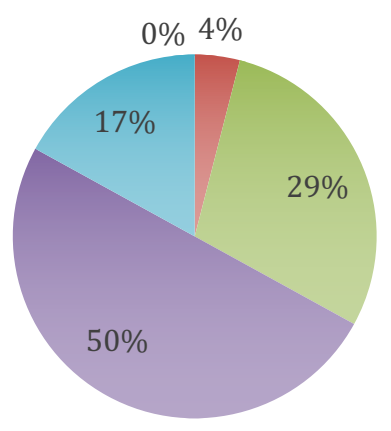

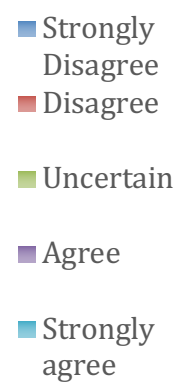

\section{Figure 8}

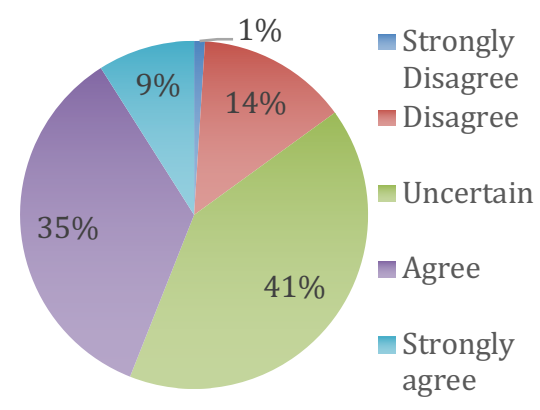

As stated in the pie chart of figure 9 on the next page, it was found that $88 \%$ of the students agreed and strongly agreed they like to enhance new vocabulary. There was nobody disagreed. It meant that most students like to enhance new vocabulary. This was the students' response from statement number 9.

Figure 10 showed that $67 \%$ of the students agreed and strongly agreed that they learn many vocabulary from the listening material. On the other hand, there nobody disagreed. It meant all of the students ever learned vocabulary from the English movies. This response was from statement number 10. The pie chart below is the result of statement number 9 and 10 . 


\section{Figure 9}

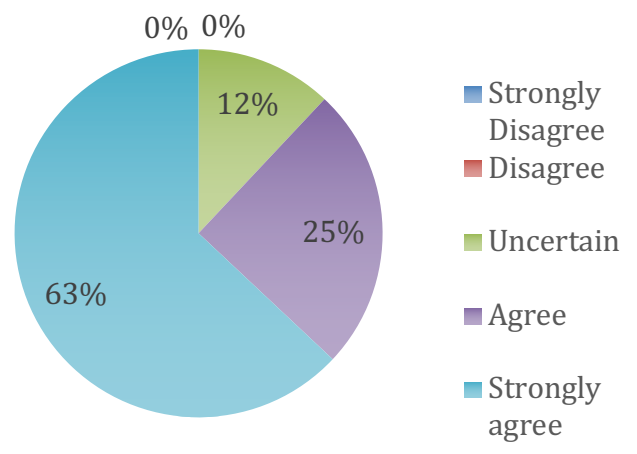

\section{Figure 10}

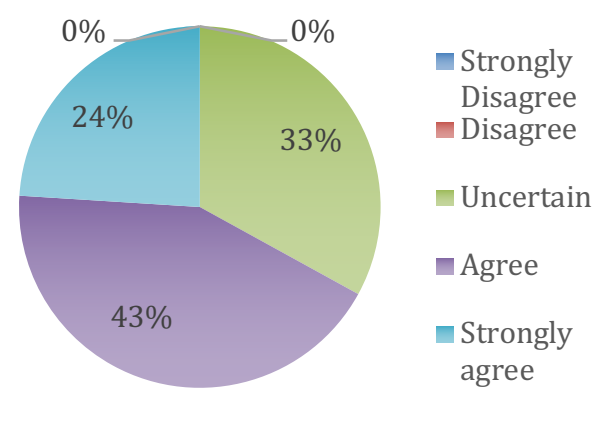

Figure 11 on the next page shows that $51 \%$ of the students agreed and strongly agreed their teacher help them learning new vocabulary every day. $12 \%$ of the students disagreed that. This response was statement number 11. The pie chart below is the result of statement number 11 .

\section{Figure 11}

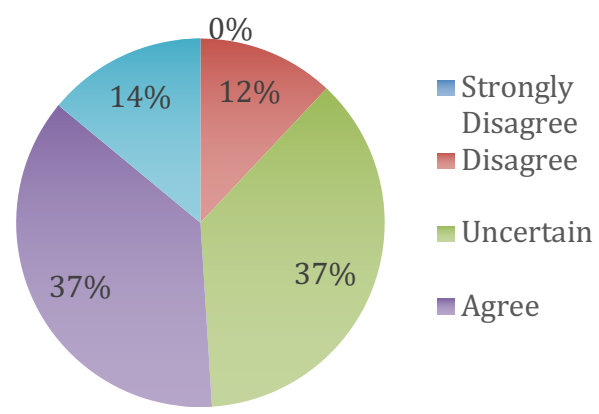

Figure 12 in the next page showed that $72 \%$ of the students agreed and strongly agreed they learn vocabulary from subtitles when they watch English movies. Only $1 \%$ of the student disagreed. It meant the most of students learned vocabulary from subtitles when they watched English movie. This response was from statement number 12. The pie chart below is the result of statement number 12.

According to the pie chart of figure 13 on the next page, it was found that $75 \%$ of the students agreed and strongly agreed they like English movies. There only $2 \%$ of the students disagreed. This response was from statement number 13 . 
The pie chart below is the result from statement number 12 and 13 .

Figure 12

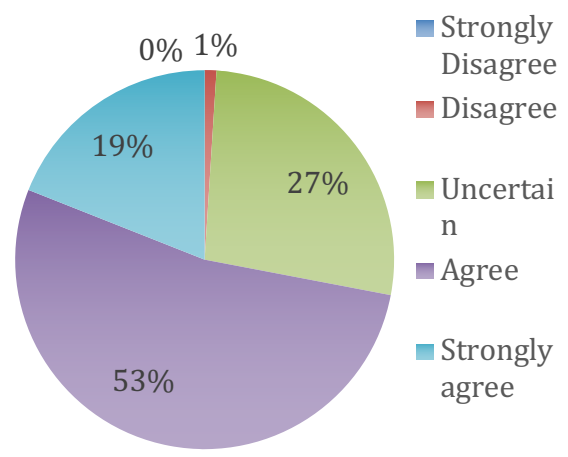

Figure 13

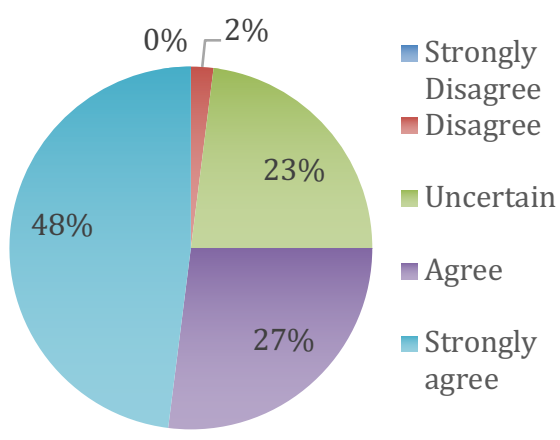

According to the pie chart of figure 14 on the next page, $64 \%$ of the students agreed and strongly agreed they record vocabulary from English soundtrack movies in their notebook. On the other hand, $22 \%$ of the students disagreed. This response was from statement number 14 .

According to the pie chart of figure 15 in the next page, it was found that $58 \%$ of the students agreed and strongly agreed that they learned vocabulary by watching the movies then they try to remember words and repeatedly. There only $12 \%$ of students disagreed. This response was from statement number 15 . The pie chart below is the result of statement numbers 14 and 15 . 


\section{Figure 14}

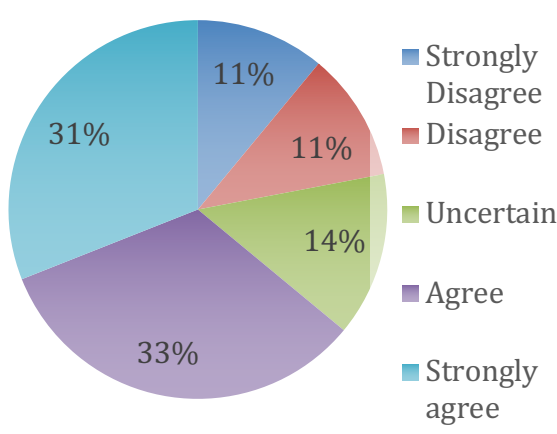

Figure 15

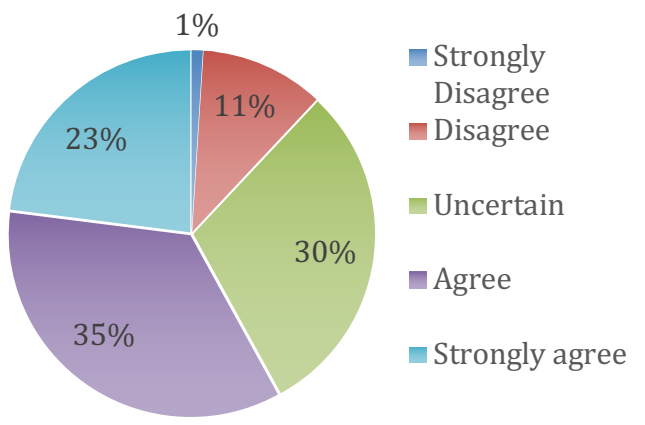

According to the pie chart of figure 16 , it was found that $34 \%$ of the students agreed and strongly agreed they did not worry very much about the disagreed. It meant when students read or listened to difficult words they could not go ahead. This response was from statement number 16. The pie chart below is the difficult words found when reading or listening, they pass them. On the other hand, $14 \%$ of the students disagreed. The result from statement number 16.

\section{Figure 16}

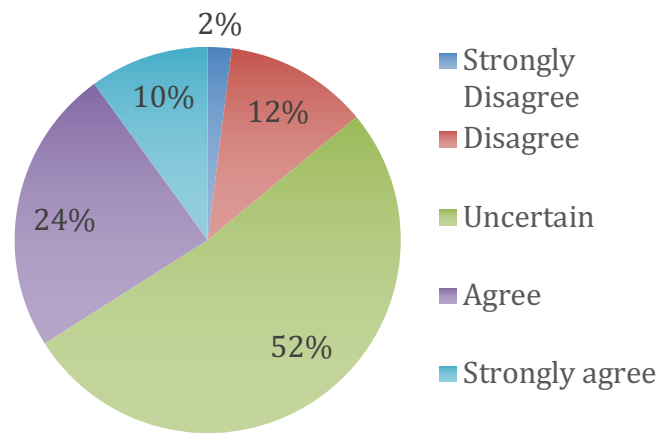

According to the pie chart of figure 17 , it was found that $53 \%$ of the students agreed and strongly agreed they use online exercise to test their vocabulary knowledge. While there only $18 \%$ of the students disagreed. This response was statement number 17.

According to the pie chart of figure $18,57 \%$ of the students agreed and strongly agreed they write a new word in a sentence so they can remember it. On the other hand, there only $9 \%$ of the student disagreed. This response was from 
statement number 18 . The pie chart below is the result of statement numbers 17 and 18.

\section{Figure 18}

\section{Figure 17}
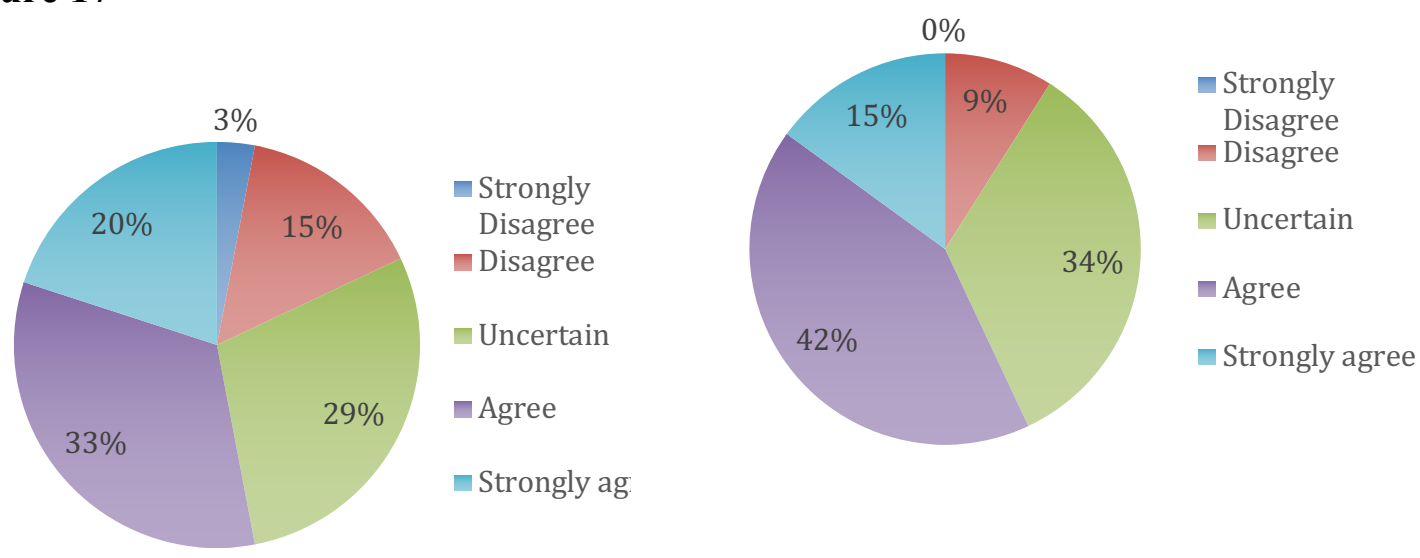

According to the pie chart of figure 19 on the next page, it was found that $58 \%$ of the students agreed and strongly agreed they speak words out loud when they study vocabulary. On the other hand, $21 \%$ of the students who participated in the questionnaire showed that they did not speak out loud when they studied vocabulary. This response was from statement number 19. The pie chart below is the result of statement number 19 .

\section{Figure 19}

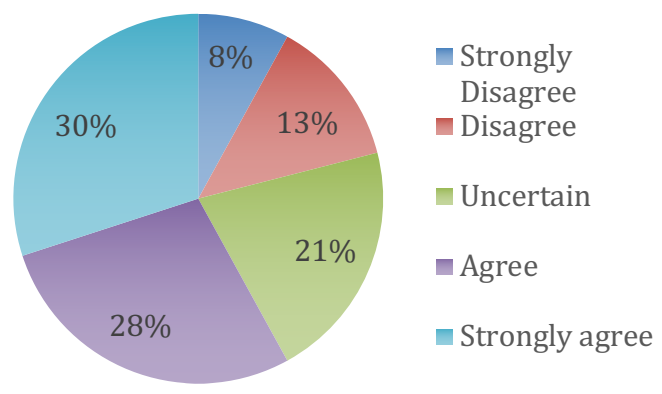

According to the pie chart of figure 20 on the next page, it was found that $39 \%$ of the students agreed and strongly agreed they prefer watching movies with 
dual subtitles. On the other hand, $29 \%$ of the students disagreed. This response was from statement number 20 statement.

According to the pie chart of figure 21 on the next page, it was found that $69 \%$ of the students agreed and strongly agreed they prefer watching movies with English subtitles. There only $6 \%$ of the students disagreed. This response was from statement number 21 . The diagram below is the result of q statement numbers 20 and 21 .

Figure 20

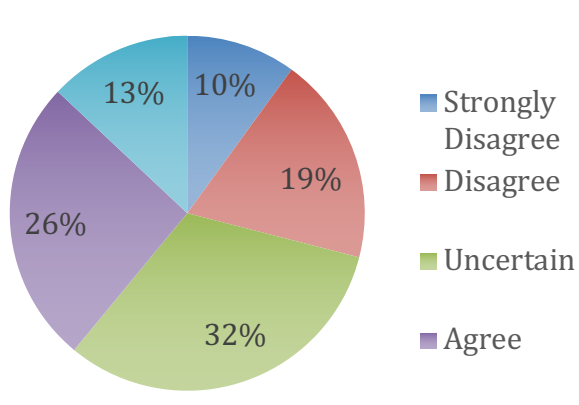

Figure 21

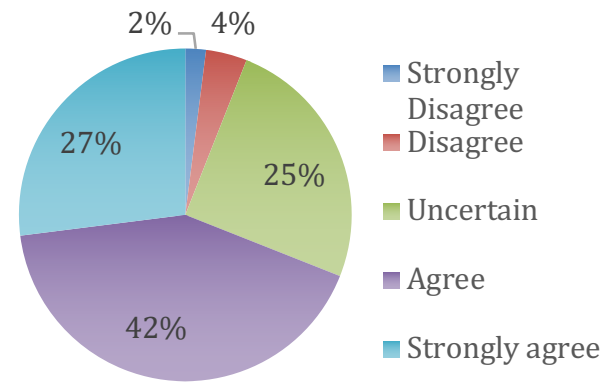

According to the pie chart of figure 22 on the next page, it was found that $54 \%$ of the students agreed and strongly agreed that they always look forward to English classes. On the other hand, there only $7 \%$ of the students disagreed. This response was from statement number 22 .

According to the pie chart of figure 23 on the next page, $52 \%$ of the students agreed and strongly agreed when they have free time to relax, they prefer to watch an English movie. There only $6 \%$ of the students disagreed. This response was from statement number 23. The pie chart below is the result of statement numbers 22 and 23. 


\section{Figure 22}

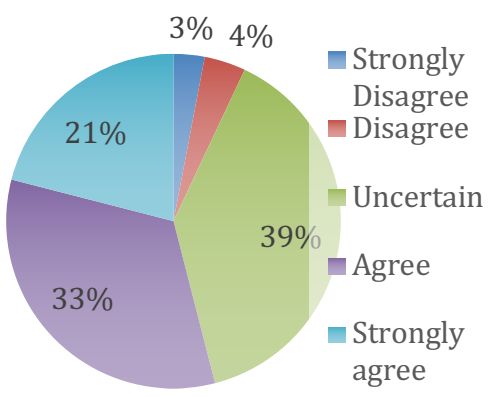

Figure 23

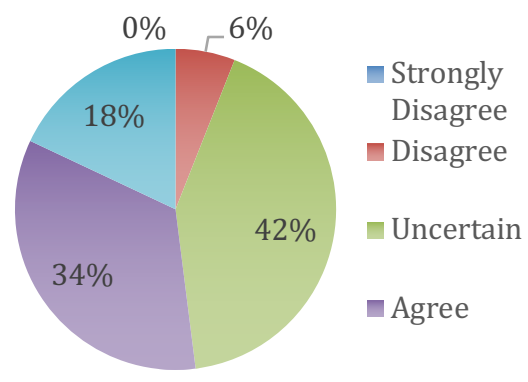

According to the pie chart of figure 24 on the next page, it was found that $67 \%$ of the students agreed and strongly agreed they try having conversations using the new words with English speakers e.g. teachers, etc. On the other hand, there only $4 \%$ of the students disagreed. From Zohdi's (2010) questionnaire's result also stated that Based on the findings, one of the effective features was students' productivity in the conversations and discussions. They tend to be more active in the discussions followed by a ten-minute movie view. This response was statement number 24.

According to the pie chart of figure .25 in the next page, $45 \%$ of the students agreed and strongly agreed that they read the new words 2 or 3 times first, again a few days later, a week later, a month later. There only $11 \%$ of the students disagreed that. This response was from statement number 25 . The pie chart below is the result of statement numbers 24 and 25.

\section{Figure 24}

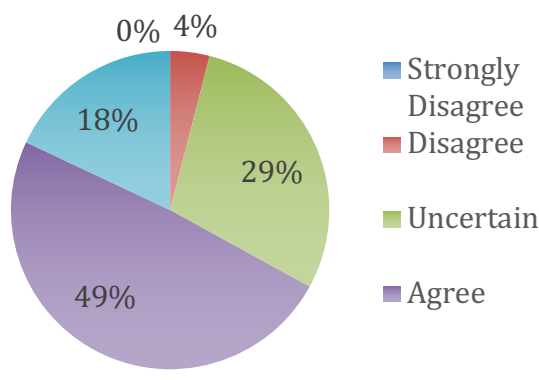

Figure 25

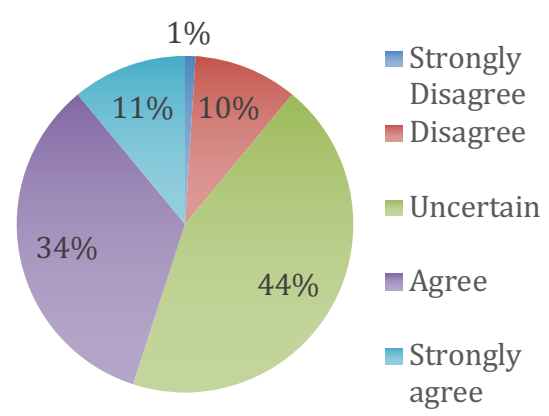


According to the pie chart of figure 4.26 on the next page, it was found that $82 \%$ of the students agreed and strongly agreed that learning vocabulary from subtitled movies is an interesting way. On the other hand, there only $2 \%$ of the students disagreed. According to Hanoi (2010, p. 20-22) notes that English movies can motivate some students to learn vocabulary and understand English better. This response was from statement number 26 .

According to the pie chart of figure 4.27 on the next page, $68 \%$ of the students agreed and strongly agreed that they prefer to learn vocabulary from subtitled movies rather than from books. In the same situation, there only $8 \%$ of the students disagreed. This response was consistent with the number 26 statement. The pie chart below is the result of statement numbers 26 and 27.

Figure

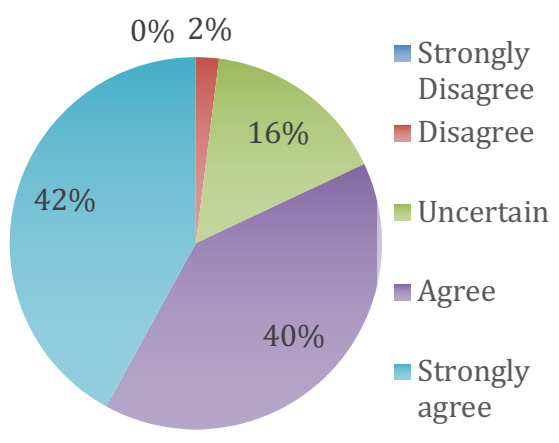

26

Figure 27

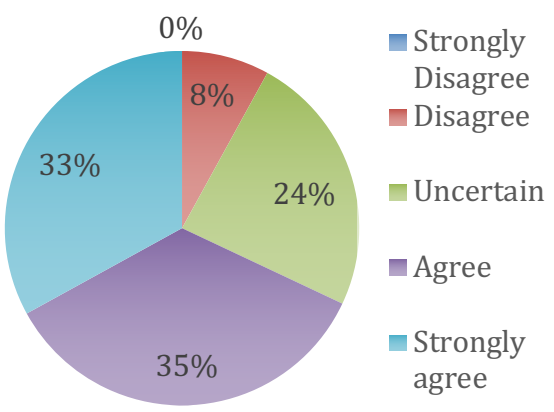

According to the pie chart of figure 28 on the next page, it was found that $74 \%$ of the students agreed and strongly agreed the subtitled movie makes vocabulary learning easy. In the same situation, there only $1 \%$ of the students disagreed. This response showed the statement number 28 .

According to the pie chart of figure 29 on the next page, $82 \%$ of the students agreed and strongly agreed that English movies improve my English vocabulary. There only $1 \%$ of the student disagreed. This response was from statement number 29 statement. The pie chart below is the result of statement numbers 28 and 29. 
Figure 28

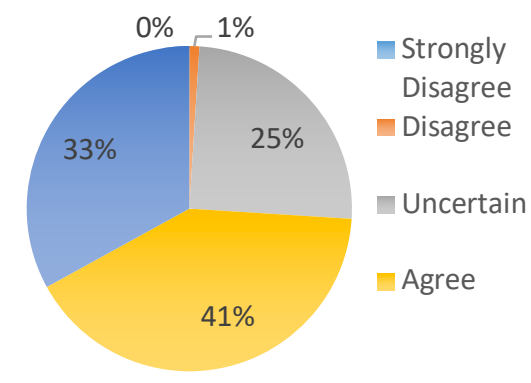

Figure 29

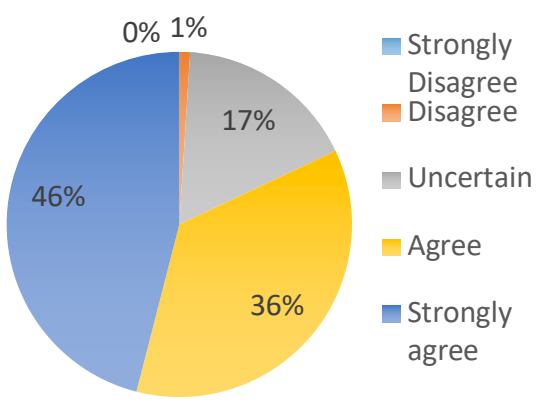

According to the pie chart of figure 30 on the next page, $59 \%$ of the students agreed and strongly agreed that Movies should be used in the EFL classroom. Only $8 \%$ of the students disagreed. This response was from statement number 30 .

According to the pie chart of figure 31 in the next page, it was found that $76 \%$ of the students agreed and strongly disagreed that they think movies are a useful resource for oral English language teaching. There nobody who disagreed. It meant that most of the students' responses agreed that movies are useful resources for oral English language teaching. This response was consistent with the number 31. Ismaili (2013) also stated that movies are a useful resource for oral English language teaching, and they emphasized that movies are a useful resource for teaching English vocabulary. This response was from statement number 31 . The pie chart below is the result of statement numbers 30 and 31 . 
Figure 30

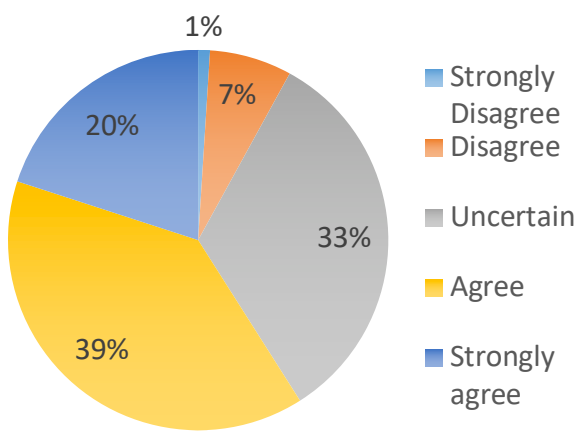

Figure 31

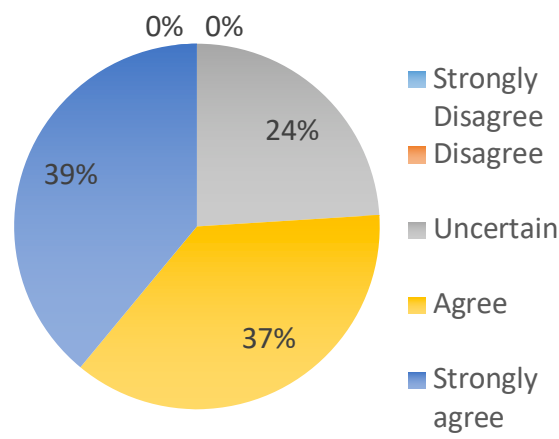

According to the pie chart of figure 32 in the next page, it was found that $75 \%$ of the students agreed and strongly agreed that the feedback I received from students when using movies in teaching has been positive. From the students' questionnaire, there was only $1 \%$ of students who disagreed. Zohdi's (2010) questionnaire result pointed out, no one was absent during the three-month course from the movie sessions and learning the unknown words had increased their selfconfidence and satisfaction in English. This response was from statement number 32. According to the pie chart of figure 33 on the next page, it was found that $76 \%$ of the students agreed and strongly agreed that they think movies are a useful resource for teaching English vocabulary. There only 3\% of the students disagreed. This response was from statement number 33. The pie chart below is the result from statement number 32 and

\section{Figure 32}

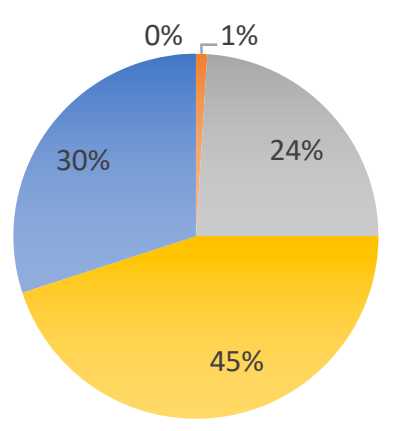

\section{Figure 33}

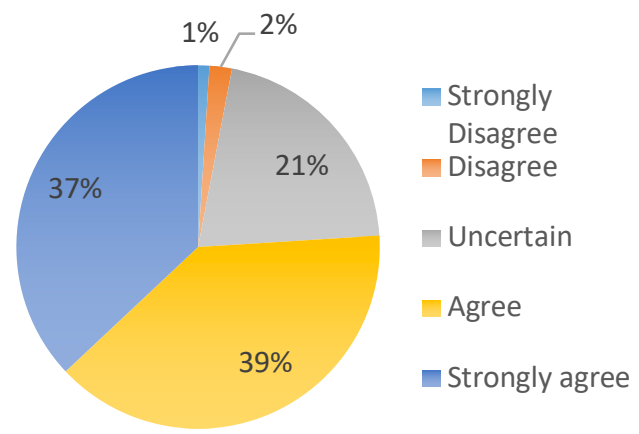

According to the pie chart of figure .34 in the next page, it was found that $75 \%$ of the students agreed and strongly agreed that a movie review is more 
motivating for the students than a book review. On the other hand, there only $3 \%$ of the students disagreed that. This response was from statement number 34 .

According to the pie chart of figure 35 on the next page, it was found that $87 \%$ of the students agreed and strongly agreed that watching English movies has a beneficial effect on learning English. From the students' response questionnaire, there was nobody who disagreed. This response was from statement number 35 . The pie chart below is the result of statement numbers 34 and 35 .

\section{Figure 34}

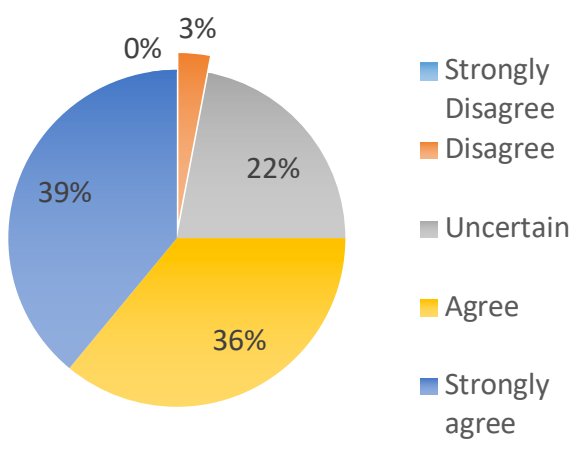

\section{Figure 4.3}

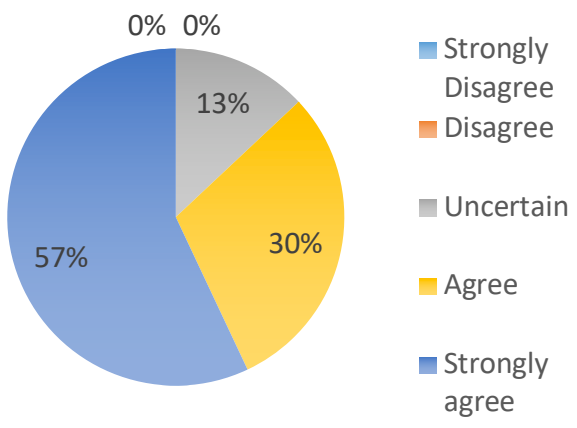


The following pie chart is the Students' questionnaire ratio about the three parts categories.

\section{Figure 36}

The Pie chart of Students' questionnaire ratio

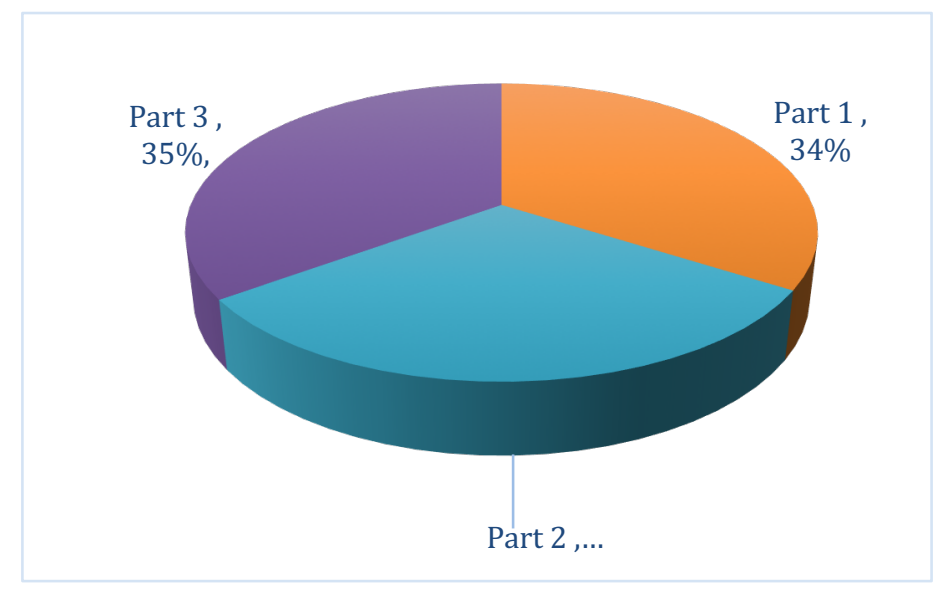

Part 1: enhancing new Vocabulary

Part 2: The Knowledge of Learning Background

Part 3: Students' Personal Feeling and Attitude toward the Implementation of Subtitled English Movies

According to the pie chart figure 4.36, the part one enhancing new Vocabulary is $34 \%$, the second part of the knowledge of Learning Background is $31 \%$, part three of the Students' Personal Feeling and Attitude toward the Implementation of Watching Movies is $35 \%$. Based on the statement of question about "What are students' responses in learning new vocabulary through watching subtitled English movies?" To be able to know the answer was from part 3 . The students' responses in enhancing new vocabulary through subtitled English movies was 35\%. Part 3 was the maximum value in all the parts of the indicator.

Based on the questionnaires being distributed to UNAI's students, the result showed that most of the students like watching subtitled English movies. Because most of the students gave positive responses related to the use of subtitled English movies in enhancing new vocabulary. In table 4.5 Putra (2014) claimed that watching English movies with subtitles can be an effective method to improve the English vocabulary. Zarei, (2009) also found that the use of movies, particularly the subtitled movies, can be one of the most enjoyable, stress-free methods for L2 vocabulary learning.

The following table shows the result analysis of the students' personal feelings and attitudes toward the implementation of watching English movies with subtitles.

Table 4.5

The Result Analysis of the Students' Personal Feeling and Attitude toward the Implementation of Watching English Movie with Subtitles.

\begin{tabular}{|l|l|}
\hline No & Result Analysis \\
\hline
\end{tabular}




\begin{tabular}{|c|c|}
\hline 1 & $\begin{array}{l}87 \% \text { of the students thought watching English movies has a } \\
\text { beneficial effect on enhancing English. (The questionnaire from } \\
\text { number } 35 \text {. The whole result can be seen in appendix E page } 82 \text { ). }\end{array}$ \\
\hline 2 & $\begin{array}{l}82 \% \text { of the students said that learning vocabulary from subtitled } \\
\text { movies is an interesting way. (The questionnaire from number } \\
26 \text {. The whole result can be seen in appendix E page } 81 \text { ). }\end{array}$ \\
\hline 3 & $\begin{array}{l}82 \% \text { of the students thought that English movies improved their } \\
\text { English vocabulary. (The questionnaire from number } 29 \text {. The } \\
\text { whole result can be seen in appendix E page } 81 \text { ). }\end{array}$ \\
\hline 4 & $\begin{array}{l}75 \% \text { of the students thought a movie review is more motivating } \\
\text { for the students than a book review. (The questionnaire from } \\
\text { number } 34 \text {. The whole result can be seen in appendix E page } 82 \text { ). }\end{array}$ \\
\hline 5 & $\begin{array}{l}75 \% \text { of the students said that they like English movies. (The } \\
\text { questionnaire from number } 13 \text {. The whole result can be seen in } \\
\text { appendix E page } 80 \text { ). }\end{array}$ \\
\hline 6 & $\begin{array}{l}59 \% \text { of the students thought movies should be used in the EFL } \\
\text { classroom. (The questionnaire from number } 30 \text {. The whole result } \\
\text { can be seen in appendix E page } 81 \text { ). }\end{array}$ \\
\hline 7 & $\begin{array}{l}69 \% \text { of the students prefer watching movies with English } \\
\text { subtitles. (The questionnaire from number } 21 \text {. The whole result } \\
\text { can be seen in appendix E page } 81 \text { ). }\end{array}$ \\
\hline 8 & $\begin{array}{l}52 \% \text { of the students said when they had free time to relax, they } \\
\text { preferred to watch English movies. (The questionnaire from } \\
\text { number } 23 \text {. (The whole result can be seen in appendix E page } \\
\text { 81). Andric (2012). Teaching vocabulary: } 50 \text { creative strategies, } \\
\text { grades K-12. New Jersey: Pearson. } \\
\text { Arikunto. (2012). Prosedur Penelitian Suatu Pendekatan } \\
\quad \text { Praktik. Edisi revisi 6.Jakarta: Rineka Cipta. }\end{array}$ \\
\hline
\end{tabular}

\section{Conclusion}

Therefore, based on the study done that six highest scores affected students' responses in enhancing new vocabulary. First, the result of the calculation shown that $82 \%$ of the students agreed that learning vocabulary from subtitled movies is an interesting way. Second, $82 \%$ of students agreed that English movies have improved their English vocabulary. Third, 87\% of the students agreed that watching English movies has a beneficial effect on learning English. Fourth, $82 \%$ of the students agreed that they can learn many new words from watching subtitled English movies. Fifth, $86 \%$ of the students agreed that they want to know the meaning when they watch 
English movie. Sixth, $88 \%$ of the students agreed that they like to enhance new vocabulary.

In like manner, there were four of the lowest score that affected students' responses in learning new vocabulary. First, $28 \%$ of the students agreed that they understand all vocabulary in their English test. Second, 44\% of the students agreed that they understand every word when their teacher speaks in English at UNAI. Third, 34\% of the students agreed that they do not worry very much about the difficult words found when reading or listening, they pass them. Fourth, 39\% of the students agreed they prefer watching movies with dual subtitles.

Based on the students' responses, it can be concluded that some of UNAI's students were weak in their vocabulary. Based on the question number three, only $28 \%$ of the students agreed they can understand when they watch subtitled English movies. And only $44 \%$ of the students agreed they understand every word when their teacher spoke in English. They had limited vocabulary to comprehend the meaning of a text; they could not recognize the meaning of each word. Accordingly, they needed an effective way to help them learn new vocabulary. Based on the question number twenty-six we can see that $82 \%$ of the students agreed learning vocabulary from subtitled movies is an interesting way. $82 \%$ of the students agreed they can learn many new words from watching subtitled English movies. Based on the question number thirty-five we can see that $87 \%$ of the students agreed watching subtitled English movies has a beneficial effect on learning English. Similarly, we can see that $74 \%$ of the students' responded that the subtitled movie made vocabulary learning easy. Further, the result shows that $75 \%$ of the students agreed a movie review is more motivating for the students than a book review.

For that, if the students learn new vocabulary through subtitled English movies, they have an interesting way to learn new vocabulary. They can learn many new words from watching subtitled English movies. On the other hand, a movie review is more motivating for the students than a book review. Likewise, The Subtitled movie makes vocabulary learning easy. Students can study well and can enjoy the learning direct. The subtitled English movie will help them to enhance their vocabulary. Similarly, it will help them to enhance another English skill.

\section{References}

Arikunto. (2012). Prosedur Penelitian Suatu Pendekatan Praktik. Edisi revisi 6.Jakarta: Rineka Cipta.

Ghozali, I. (2005) Aplikasi Analisis Multivariate Dengan Program SPSS. Semarang: Badan Penerbit Universitais Diponegoro.

Hanoi (2010). Using movies and videos to teach English vocabulary to the 10th

Ismaili, M. (2013). The effectiveness of using movies in the EFL classroom issues. Mahwah, NJ: Lawrence Erlbaum. 
Katemba, C., V. (2013), Anxiety Level of Indonesian Students and Its Relationship To Academic Achievement In English. Journal of Education and Practice Vol.4 No.27 pp. 1-9. Retrieved from http://www.iiste.org/Journals/index.php/JEP/article/view/9873/10097

King, J. (2002, February). Using DVD feature films in the EFL classroom. ELT Newsletter, The weekly column.

Lein (2006). Teaching vocabulary through pictures to the kindergarten students. Jakarta: Universitas Negri Islam Syarif Hidayahtullah.

Leung, W. (2001). How to design a survey. STUDENTBMJ VOLUME 9.

Manchester. O And Ihedigbo Chinedum E. (2014) Research Designs, Survey and Case Study. IOSR Journal of VLSI and Signal Processing (IOSR-JVSP) Volume 4, Issue 6, Ver. I (Nov - Dec. 2014), PP 16-22 e-ISSN: 2319 4200, pISSN No. : 23194197 www.iosrjournals.org

Nguyen T H \& Khuat T N, (2003). The Effectiveness of Learning Vocabulary Through Games: the effectiveness of learning vocabulary through Games December 2003 Available from http://asian-efl-journal.com/dec 03 vn.pdf

Putra. P. (2014) Learning vocabulary using English movie with subtitles in SMK Santo Yoseph Non-Regular English Program Faculty of Letters and Culture Udayana University.

Schmitt, N. (2000). Vocabulary in language teaching. Cambridge: Cambridge University Press.

Shoebottom, (2010). The importance of vocabulary. Frankfurt international school, Available at https:// esl.fis.edu/ parents/ advice/ vocab.htm, accessed on 16th January (2012)

Sukrina, V. (2010). Improving Students' Vocabulary Mastery by Using Realia. English Department, Faculty of Languages and Art. State University of Medan.MedanIndonesia. http://jurnal.unimed.ac.id/2012/index.php/jelt/article/view/913

Wilkins, D. A. 1972. Linguistics in Language Teaching. London: Arnold.

Zohdi, N, (2010) The impact of using movie clips on students' vocabulary learning in language classrooms 